\title{
The influence of pistia powder (Pistia stratiotes $L$.) in ration on the performance index and red blood cell profile of male Magelang duck
}

Eka Rizky Fatmawati, Teysar Adi Sarjana*, Edjeng Suprijatna, Siswanto Imam Santoso, and Agus Setiadi

Poultry Farm Production, Husbandry Study Program, Husbandry Departement, Husbandry and Agriculture Faculty, Universitas Diponegoro, Semarang, Indonesia

Submitted: 10 December 2019, Accepted: 01 March 2021

\begin{abstract}
The research aims at studying the influence of pistia powder (Pistia stratiotes $L$.) as feed material on the performance index and red blood cell profile of male Magelang duck. The materials used were 100 heads of 4 -week old male Magelang duck. The treatments were: T0 (basal), pistia powder in T1, T2 and T3 of ration for male Magelang duck at $6 \%, 12 \%$ and $18 \%$. The parameters observed were Performance Index (PI), number of erythrocytes, amount of hemoglobin, hematocrit level, MCV (Mean Corpuscular Volume), MCH (Mean Corpuscular Hemoglobin) and MCHC (Mean Corpuscular Hemoglobin Concentration). The research results showed that using pistia powder up to $18 \%$ significantly $(\mathrm{P} \leq 0.05)$ increased performance index $(\mathrm{PI})$ and generally insignificantly $(\mathrm{P}>0.05)$ influenced the number of erythrocytes, amount of hemoglobin, hematocrit level, MCV and MCHC, but significantly decreased $(\mathrm{P}<0.05) \mathrm{MCH}$. The research concludes that pistia powder may be used up to $18 \%$ in ration to increase the performance index without influencing the red blood cell profile of male Magelang duck.
\end{abstract}

Keywords: Male Magelang Duck; Pistia; Performance Index; Red blood profile

*Corresponding Author: teysaradisarjana@lecturer.undip.ac.id 


\section{INTRODUCTION}

Magelang duck is farmed in Magelang Regency as an Indonesian local duck, with its distinguishing characteristics of having white collar around its neck and generally brown or black feathers. The advantage of male Magelang duck is that it may produce meat (Decree of Minister of Agriculture, 2013). Male Magelang duck has heavier body weight than Mojosari and Tegal ducks, with their respective weight of 1710 grams, 1570grams and 1430grams (Febrianto et al., 2018), and relatively rapid growth, as indicated with its superior body at the same age, making Magelang duck potential duck for food.

The ducks are farmed semiintensively since it still relies on local, nonconventional feed materials, as marked with relatively high content of crude fiber. High crude fiber in ration may inhibit nutrient adsorption process, reduce digestibility and inhibit formation of body tissues, which are muscle and blood. Tolerable crude fiber content in ration for duck is $10 \%$ (Sutrisna, 2011). Eight weeks old pekin duck given with ration containing $10.22-11.32 \%$ crude fiber shows significant increase in live weight, carcass weight and carcass cut weight (Daud et al., 2017). Based on the research result, we may conclude that nonconventional feed material with certain level of crude fiber is still usable in duck ration, since it may significantly increase duck's performance.

An observation of performance index should include blood physiological condition, which is one indicator of animal welfare (Prayitno and Sugiharto, 2002). An effort to improve farming effectiveness may be made through using alternative feed material which does not contradict to animal welfare, thus physiological observation on red blood cell profile serves as an additional indicator of good animal welfare. Good psysiological condition in the poultry illustrate that the transport of nutrients and oxygens in the body are optimal, so it can produce good performance (Mahmud et al., 2017). The performance index is produced from the components of good performance as well, including of body weight, feed consumtion ratio (FCR) and mortality. So when the duck has a good red blood cell profile, it is expected to optimize the performance index.

Pistia powder (Pistia stratiotes L.) is one type of local, non-conventional feed material which starts to be used.Pistia stratiotes $L$. is a aquatic plant that serves as a phytoremediation and contains minerals, metallic, amino acids and inulin (Bauddh, Singh and Korstand, 2017). Pistia powder usage needs to be limited to a certain level for adjustment of the fiber and metal contents in ration for duck. The concentration of $\mathrm{Fe}, \mathrm{Zn}, \mathrm{Cu}, \mathrm{Ca}$ and $\mathrm{P}$ in ration for duck may influence consumption and giving it excessively may influence livestock's physiology (Levengood et al., 2000). A research on the use of pistia powder up to $30 \%$ in ration for ayam kampung results in an increase of HDL (High Density Lipoprotein), a decrease of LDL (Low Density Lipoprotein) level and a significantly different decrease of total cholesterol in meat (Sutama, 2005). Pistia powder in feed for male Magelang duck in this research contains inulin of almost $2 \%$ (Unpublish).Inulin $0.4 \%$ in ration may significantly increase broiler's body weight compared with inulin-less ration(Daud et al., 2016).

The objective of this research is to study the influence of pistia powder (Pistia stratiotes L.) as feed material on the performance index and red blood cell profile of male Magelang duck. The advantage of this research is to examine an optimal usage of pistia powder for good performance index and red blood cell profile of male Magelang duck. The research's hypothesis is that using pistia powder up to $18 \%$ in ration for male Magelang duck may improve performance index without influencing red blood cell profile. 


\section{MATERIALS AND METHODS}

The research was conducted at the Poultry Production Laboratory, Faculty of Animal Agriculture, Diponegoro University, Semarang. The research's materials were 100 heads of 4-week old male Magelang duck with average body weight of $498.89 \pm 116.03 \mathrm{~g}$. Twenty units of duck coop are equipped with their equipment. The ducks are raised from $4-9$ weeks old. The treatments were usage of pistia powder (Pistia stratiotes L.) in ration for male Magelang duck at different levels of T0 $0 \%, \mathrm{~T} 16 \%$, T2 $12 \%$ and T3 18\%. The composition of ration for male Magelang duck, the results of analysis on pistia powder (Pistia stratiotes L.) as ration andthe results of proximate analysis on the nutrients in ration for male Magelang duck used in the research may be viewed in Table 1 and 2 .

Table 1. Composition of Ration for Male Magelang Duck

\begin{tabular}{lcccc}
\hline \multicolumn{1}{c}{ Feed material } & $\mathrm{T} 0$ & $\mathrm{~T} 1$ & $\mathrm{~T} 2$ & $\mathrm{~T} 3$ \\
\hline Corn & 57.54 & 57.00 & 58.10 & 57.76 \\
Pistia stratiotes L. Powder & 0.00 & 6.00 & 12.00 & 18.00 \\
Soybean Meal & 14.04 & 12.39 & 10.89 & 8.51 \\
Oil & 1.71 & 1.40 & 1.32 & 1.26 \\
Bran & 14.54 & 12.79 & 7.10 & 4.26 \\
Fish meal & 6.74 & 7.00 & 7.58 & 0.67 \\
$\mathrm{CaCO}_{3}$ & 1.24 & 0.35 & 0.15 & 0.26 \\
Premix & 1.74 & 1.00 & 0.90 & 0.26 \\
Methionine & 0.74 & 0.07 & 0.60 & 0.76 \\
Lysine & 1.74 & 2.00 & 1.36 & 100.00 \\
\hline Total & 100.00 & 100.00 & 100.00 & \\
\hline
\end{tabular}

Table 2. Results of Proximate Analysis on the Nutrients in Ration for Male Magelang Duck (As Feed)

\begin{tabular}{lcccc}
\hline Nutrient Content & T0 & T1 & T2 & T3 \\
\hline Metabolic Energy (kkal/kg)* & 3224.79 & 3225.32 & 3181.57 & 3201.36 \\
Water (\%) & 11.40 & 11.36 & 10.99 & 11.60 \\
Crude Protein $(\%)$ & 15.30 & 15.33 & 14.46 & 15.16 \\
Crude Fat $(\%)$ & 2.10 & 1.80 & 1.87 & 1.98 \\
Crude Fiber $(\%)$ & 11.62 & 10.44 & 9.53 & 9.37 \\
Ash (\%) & 5.81 & 6.60 & 8.83 & 8.57 \\
Ca (\%) & 1.54 & 1.37 & 0.84 & 1.36 \\
P $(\%)$ & 0.59 & 0.67 & 0.41 & 0.71 \\
\hline
\end{tabular}

Explanation:

(*) Metabolic Energy based on Bolton formula $=40.81(0.87(\mathrm{PK}+2.25 \mathrm{LK}+\mathrm{BETN})+4.9)$ (Sugiharto et al., 2017).

The research was conducted by using a Completely Randomized Design (RAL) with 4 treatments and 5 repetitions. The parameters observed were performance index and red blood cell profile including erythrocyte, hemoglobin, hematocrit, MCV (Mean Corpuscular Volume), MCH (Mean Corpuscular Hemoglobin) and MCHC
(Mean Corpuscular Hemoglobin Concentration). The performance data were collected during the research period. Performance index (PI) is calculated based on ducks' average body weight, percentage of live ducks, FCR (Feed Conversion Ratio) and harvest age obtained during raising period.The formula of Performance index $(\mathrm{PI})$ is:

$$
\begin{aligned}
\text { Performance index }= & \frac{\text { Average body weight }(\mathrm{kg}) \times \text { live ducks }(\%)}{\text { Feed Conversion Ratio } \times \text { harvest age }(\text { days })} \times 100 \% \\
& (\text { Nabizadeh, 2012) }
\end{aligned}
$$


Blood samples were collected at 8 weeks old for $\pm 2 \mathrm{ml}$ from brachial vein in the wing into EDTA (Ethylene Diamine Tetra Acetic Acid) tube vacutainer for blood not to clot. An electrical impedance method was used to examine red blood cell profile using hematology analyzers of sysmex corporation type (Fujimoto, 1999).

\section{RESULT AND DISCUSSION}

The research results showed Performance index (PI) and red blood cell profile of male Magelang duck as presented in Table 3. Using pistia powder up to $18 \%$ in rationsignificantly increased the performance index and, generally, there was no significant change to red blood cell profile, while significant change only occurs to $\mathrm{MCH}$ (Mean Corpuscular Hemoglobin) parameter.

\section{Performance index (PI)}

Based on the analysis of variance, using pistia powder up to $18 \%$ in ration significantly increased the performance index of male Magelang duck. The outcome of performance index in this research was better than that in the research conducted by Hadiatry and Haryani (2017), in which the average performance index of red male duck was 74.45 .

The higher performance index in this research was influenced by ducks' low average consumption and low percentage of mortality of which age was equal to that in the research conducted by Hadiatry and Haryani (2017). Using pistia powder up to $18 \%$ in ration for Magelang duck results in good performance, thus optimal performance index value was obtained. Pistia powder's nutrients content, especially specific amino acid consisting of glutamic acid, inulin and crude fiber, expectedly supported improvement of the performance of male Magelang duck. An increase of ration consumption in male Magelang duck treated with pistia powder $18 \%$ in ration was expectedly influenced by relatively high content of glutamic acid in pistia powder.

Table 3. Performance index and red blood cell profile of male Magelang duck in grower phase

\begin{tabular}{lcccc}
\hline \multirow{2}{*}{ Parameter } & \multicolumn{4}{c}{ Treatment } \\
\cline { 2 - 5 } & $\mathrm{T} 0$ & $\mathrm{~T} 1$ & $\mathrm{~T} 2$ & $\mathrm{~T} 3$ \\
\hline Performance index & $65.81 \pm 7.83^{\mathrm{b}}$ & $83.16 \pm 15.35^{\mathrm{a}}$ & $78.91 \pm 8.86^{\mathrm{ab}}$ & $89.95 \pm 8.05^{\mathrm{a}}$ \\
Erythrocyte $\left(10^{6} / \mathrm{L}\right)$ & $2.70 \pm 0.34$ & $2.50 \pm 0.14$ & $2.45 \pm 0.37$ & $2.53 \pm 0.18$ \\
Hemoglobin $(\mathrm{g} /$ deciliter) & $14.10 \pm 1.60$ & $12.90 \pm 0.74$ & $12.90 \pm 1.88$ & $12.60 \pm 1.08$ \\
Hematocrit $(\%)$ & $35.40 \pm 5.52$ & $31.10 \pm 2.25$ & $30.10 \pm 3.45$ & $31.70 \pm 2.61$ \\
MCV (femtoliter) & $131.86 \pm 5.75$ & $125.26 \pm 3.60$ & $124.66 \pm 9.84$ & $126.56 \pm 2.51$ \\
MCH (picogram) & $52.28 \pm 1.48^{\mathrm{a}}$ & $51.56 \pm 1.92^{\mathrm{ab}}$ & $52.62 \pm 0.55^{\mathrm{a}}$ & $49.74 \pm 1.65^{\mathrm{b}}$ \\
MCHC (gram/deciliter) & $40.02 \pm 1.78$ & $41.50 \pm 2.09$ & $42.82 \pm 3.45$ & $39.70 \pm 1.33$ \\
\hline
\end{tabular}

Explanation: Different superscript in the same line shows significant difference $(\mathrm{P} \leq 0.05)$.

Based on our study, the highest glutamic content in pistia powder was $2.4 \%$ and the average glutamate consumption in ration was $2.5 \mathrm{~g} / \mathrm{head} / \mathrm{day}$, which will influence ration palatability. This conformed to the research conducted by Khadiga et al. (2009) that an increase of glutamate consumption may influence rationpalatability, and an addition of up to $1 \%$ monosodium glutamate in broilers' ration significantly increased ration consumption. Based on the research conducted by Sukmaningsih et al. (1998), addition of glutamic acid up to $10.08 \%$ into male broilers' ration significantly increased glutamate consumption. The performance index value of male Magelang duck consuming ration with $18 \%$ pistia powder significantly increased because of an increase of glutamate consumption in ration. Pistia powder used in this research contains inulin, in which inulin content in treatment ration up to $0.3 \%$ may significantly increase the performance index of male Magelang duck. This conforms to the research conducted by Nabizadeh (2012) that an addition of $0.5 \%$ and $1 \%$ inulin into chicken ration significantly increased performance 
index, while another research conducted by Daud et al. (2016) stated that an addition of $0.4 \%$ inulin into ration significantly increased broiler's body weight, because of an increase of lactic acid bacteria in digestive tract. Inulin content in ration served to help optimize nutrient adsorption by activating gut bacteria, thus the performance generated will be more optimal. This conformed to the statement of Fanani et al. (2017) that using inulin as prebiotic in duck ration may increased and activate gut bacteria and thus optimize nutrient adsorption and increased body weight. Inulin content in ration was not too high, but may significantly increased the performance index of Magelang duck.

Pistia powder $18 \%$ used in this research's rationcontains $9.37 \%$ crude fiber, of which condition may expectedly increase performance index and according to Mangisah et al. (2007), $15 \%$ crude fiber in rationmay still maintain duck's performance.Based on our research, the crude fiber content in ration with $18 \%$ pistia powder decreased $24.01 \%$ from control ration. The high crude fiber in control ration expectedly slowed down ration digestibility as marked with low ration consumption and body weight, thus duck's performance index was lower than that of other treatments. This conformed to the opinion of Rompas et al. (2016) that the increase in rough fiber of the ration affected the digestibility of the ration consumed, so that the movement rate of the ration consumed was faster.

An increase in the performance index of male Magelang duck occurred to the treatment of pistia powder up to $18 \%$ in ration, indicating that Magelang duck farming got more successful. This conformed to the opinion of Fitro et al. (2015) that higher performance index will reduce the percentage of duck raising cost, thus we may state that duck raising is a success. The successful maintenance of duck is also shown from the low production cost the use of $18 \%$ pistia powder in the ration. Based on the research conducted by Setyaningrum et al. (2014) the increase in economic value on the maintenance of livestock affected by a high performance, followed by the low cost of livestock production.

\section{Red blood cell profile}

Using pistia powder up to $18 \%$ in ration for male Magelang duck did not cause significant difference $(\mathrm{P}>0.05)$ in the generally observed parameters and the significantly declining difference $(\mathrm{P} \leq 0.05)$ only occurs to $\mathrm{MCH}$ (Mean Corpuscular Hemoglobin). The number of erythrocytes, amount of hemoglobin and hematocrit level of male Magelang duck in the research are within normal range, pursuant to the other researches on the number of erythrocytes of $2.30-2.88 \times 10^{6} / \mathrm{L}$, amount of hemoglobin of $10-13 \mathrm{~g} /$ deciliter and hematocrit level of 27.10 - $37.2 \%$ (Sumiati et al. (2016), Fitrohdin et al. (2014) ${ }^{\text {and }}$ Bhattacherjee et al. (2018)). This shows that treatment of pistia powder up to $18 \%$ in ration is still a good application, since the number of erythrocytes, amount of hemoglobin and hematocrit level of male Magelang duck are still within normal range.

That using pistia powder up to $18 \%$ in ration did not significantly influence the number of erythrocytes, amount of hemoglobin and hematocrit levels. It is expectedly because the nutrient components which form red blood cell profile are fulfilled, particularly protein components. This conformed to the opinion of Reron et al. (2016) that protein was an important component to compose red blood profile and an increase of ration consumption will be followed with an increase of protein consumption. In our research, the protein consumption of $\mathrm{T} 0$ (control ration) to $\mathrm{T} 3$ (using 18\% pistia powder) has fulfilled the need for $14-16 \mathrm{~g} / \mathrm{head} /$ day (unpublished) and there is an increase of protein consumption with T3 of $9.06 \%$, thus there will be no significant influence on the formation of red blood cell profile in general. Based on the research conducted by Supriyadi (2010), the protein consumption of up to 9 -week old local ducks is optimally $12 \mathrm{~g} / \mathrm{head} /$ day for physiological needs. The 
sufficient protein consumption in this research expectedly contributes to increasing duck's body weight, thus greater relative blood volume is resulted. This shows that an improvement of protein consumption does not improve corrective components in blood cells since they are fulfilled, but improves growth rate which is followed with a change in the total blood volume instead. The normal condition of red blood cell profile with the use of pistia powder up to $18 \%$ in ration for Magelang duck is marked with the production of number of erythrocytes which is relatively in line with hematocrit and blood volume.

The MCV (Maen Corpuscular Volume) value resulted by each treatment is still in normal category, conforming to the results of research conducted by Fitrohdin et al. (2014) that Magelang duck had MCV value of 128.39 - 137.23 femtoliter. Based on the research result, normal MCV (Mean Corpuscular Volume) value may be taken as an indicator of livestock's health, thus the ducks are healthy. This conformed to the research conducted by Dalai et al. (2015) that normal MCV is an indicator to determine livestock's health as observed based on livestock's average number of erythrocytes. The MCHC in our research is also within normal range, conforming to the research conducted by Tadjalli et al. (1996) and Bhattacherjee et al. (2018) that duck's MCHC value is $41.02 \mathrm{gram} /$ deciliter and $27.59-34.19$ gram/deciliter. In this research, although $\mathrm{MCV}$ and $\mathrm{MCHC}$ values are insignificantly different, the $\mathrm{MCH}$ value has shown a significant decrease in the use of pistia powder $18 \%$. Using pistia powder up to $18 \%$ in rationsignificantly decreases $\mathrm{MCH}$ value, but the value obtained is still within normal range, pursuant to the research conducted by Zapletal et al. (2017) that duck's $\mathrm{MCH}$ value is $44.50-53.60$ picogram, thus it may generally result in better performance index than the other treatments.

That the MCH value is significantly different is influenced by the number of erythrocytes and the amount of hemoglobin.
A decrease of $\mathrm{MCH}$ is generally followed with a change in the other erythrocyte index value, but in this research, the decrease only occurred to $\mathrm{MCH}$, and normal $\mathrm{MCV}$ and MCHC values did not cause crucial change to erythrocyte index and even positively influence performance index. The relatively same result occurs to the research conducted by Zeng et al. (2015) that a significant decrease in $\mathrm{MCH}$ of $4.6 \%$ did not generally influence duck's red blood cell profile and performance. In our research, the decrease in $\mathrm{MCH}$ does not influence the other erythrocyte index value, and may also optimize performance index.

\section{CONCLUSIONS}

Based on the research results, that pistia powder with level $18 \%$ could be used in the ration of male Magelang duck's without influencing its red blood cell profile, even be optimizing index performance.

\section{REFERENCES}

Bauddh, K., Singh, B., \& Korstad, J. (2017). Phytoremediation Potential of Bioenergy Plants. Springer Nature.

Bhattacherjee, A., Acharya, C. P., Rana, N., Mallik, B. K., \& Mohanty, P. K. (2018). Haematological and morphometrical analysis of blood cells of Khaki Campbell duck (Anas platyrhynchos) in different age groups with respect to sexual dimorphism. Comparative Clinical Pathology, 27(6), 1465-1472. https://doi.org/10. 1007/s00580-018-2758-6

Dalai, M., Puspamitra, S., Bhattacherjee, A., Acharya, D., Acharya, G., \& Mohanty, P. K. (2015). Comparative haematology of Anas platyrhynchos (Anseriformes) \& Coturnix coturnix Japonica (Galliformes). Journal of Entomology and Zoology Studies, 3(5), 50-53.

Daud, M, Mulyadi, \& Fuadi, Z. (2017). Carcass persentage of Peking duck feed wafer complate ration containing of coffe waste. Journal Agripet, 16(2), 62-68. 
Daud, Muhammad, Piliang, W. G., Wiryawan, K. G., \& Setiyono, A. (2009). Penggunaan Prebiotik Oligosakarida Ekstrak Tepung Buah Rumbia (Metroxylon sago Rottb.) dalam Ransum terhadap Performan Ayam Pedaging. Jurnal Agripet, 9(2), 15-20. https://doi.org/10.17969/agri pet.v9i2.624

Fanani, A. F., Suthama, N., \& Sukamto, B. (2017). Retensi nitrogen dan konversi pakan ayam lokal persilangan yang diberi ekstrak umbi dahlia (Dahlia variabilis) sebagai sumber inulin. Sains Peternakan, 13(2), 69-75. https:// doi.org/10.20961/sainspet.v12i2.4762

Febrianto, F., Ismoyowati, I., Mufti, M., Prayitno, P., \& Purwantini, D. (2019). Polymorphisme gene GH and morphological characteristic of anas platyrhynchos and cairina moschata. Animal Production, 20(1), 17-27. https: //doi.org/10.20884/1.jap.2018.20.1.665

Fitro, R., \& Dihansih, E. (2017). Performa ayam pedaging yang diberi ransum komersial mengandung tepung ampas kurma sebagai pengganti jagung. Jurnal Peternakan Nusantara, 1(1), 1-8.

Fitrohdin, A., Samsi, M., \& Indrasanti, D. (2014). Erythrocyte index of female Tegal duck, Mojosari duck \& Magelang ducks fed with probiotic supplementation with different level. Jurnal Ilmiah Peternakan, 2(1), 42-51.

Fujimoto, K. (1999). Principles of measurement in hematology analyzers manufactured by sysmex corporation. Sysmex J Int, 9(1), 31-44.

Hadiatry, M. C., \& Haryani, D. (2017). Introduction of Fetteing Duck Production as one of Farmers' Income Source in Banten Province. Prosiding Seminar Nasional Teknologi Peternakan Dan Veteriner, 506-513.

Keputusan Menteri Pertanian. (2013). Penetapan Rumpun Itik Magelang Pembibitan.

Khadiga, Ati, A. A., Mohammed, S., Saad, A. M., \& Mohamed, H. E. (2009). Response of broiler chicks to dietary monosodium glutamate. Pakistan Veterinary Journal, 29(4), 165-168.

Levengood, J. M., Sanderson, G. C., Anderson, W. L., Foley, G. L., Brown, P. W., \& Seets, J. W. (2000). Influence of diet on hematology \& serum biochemistry of zinc-intoxicated mallards. Journal of Wildlife Diseases, 36(1), 111-123. https://doi. org/10.7589/0090-3558-36.1.111

Mahmud, A. T. B. A., Afnan, R., Ekastuti, D. R., \& Arief, I. I. (2017). Blood profile performans \& meat quality of crossed kampung Broiler chicken in different stocking density. Jurnal Veteriner, 18(2), 247-256. https://doi. org/10.19087/jveteriner.2017.18.2.247

Mangisah, I., Nasoetion, M. H., Murningsih, W., \& Arifah. (2007). Effect of crude fiber on growth performance, vfa absorbtion of Tegal duck. Jurnal Majalah Ilmiah Peternakan, 10(1), 1-16.

Nabizadeh, A. (2012). The effect of inulin on broiler chicken intestinal microflora, gut morphology, and performance. Journal of Animal and Feed Sciences, 21(4), 725-734. https:// doi.org/10.22358/jafs/66144/2012

Prayitno, D. S., \& Sugiharto. (2002). Kesejahteraan Dan Metode Penelitian Tingkah Laku Unggas. Badan Penerbit Universitas Diponegoro.

Reron, Z. R. P., Sutrisna, R., \& Siswanto. (2016). Effect of different content of rough protein ration againts red cell count, hemoglobin, \& hematocrit of male Duck. Jurnal Ilmiah Peternakan Terpadu, 4(4), 323-327.

Rompas, R., Tulung, B., Mandey, J. S., \& Regar, M. (2016). Penggunaan eceng gondok (Eichhornia crassipes) terfermentasi dalam ransum itik terhadap kecernaan bahan kering dan bahan organik. ZOOTEC, 36(2), 372378. https://doi.org/10.35792/zot.36.2 .2016 .12539

Sugiharto, S., Yudiarti, T., Isroli, I., Widiastuti, E., \& Putra, F. D. (2017). Effects of feeding cassava pulp fermented with Acremonium 
charticola on growth performance, nutrient digestibility and meat quality of broiler chicks. South African Journal of Animal Science, 47(2), 130-138. https://doi.org/10.4314/sajas .v47i2.4

Sukmaningsih, S., Kamal, M., \& Zuprizal. (1998). Addition of glutamic acid to a low protein balance amino acids diet on performance, carcass, \& fad deposition of broiler. Buletin Peternakan, 22(1), 25-37.

Sumiati, Darmawan, A., \& Wiryawan, K. G. (2016). Egg quality and blood hematology of magelang laying duck fed with diets containing different ratios of omega 3 and omega 6 fatty acids and organic $\mathrm{Zn}$. International Journal of Poultry Science, 15(11), 448-453. https://doi.org/10.3923/ijps. 2016.448.453

Supriyadi. (2010). Panduan Lengkap Itik. Penebar Swadaya.

Sutama, I. N. (2005). Pengaruh suplementasi kapu-kapu (Pistoia stratiotes L) dalam ransum terhadap kolesterol pada serum dan daging ayam kampung. Majalah Ilmiah
Peternakan, 8(2), 1-9.

Wasagu, R. S., Lawal, M., Shehu, S., Alfa, H. H., \& Muhammad, C. (2014). Nutritive values, mineral and antioxidant properties of pistia stratiotes (Water lettuce). Nigerian Journal of Basic and Applied Sciences, 21(4), 253-257. https://doi. org/10.4314/njbas.v21i4.2

Zapletal, D., Kudělková, L., Šimek, V., Jakešová, P., Macháček, M., Straková, E., \& Suchý, P. (2017). Haematological indicators in hybrid mallard ducks (Anas platyrhynchos) with regard to the use of meal from whole white lupin seeds in their diet. Acta Veterinaria Brno, 86(3), 309315. https://doi.org/10.2754/avb2017 86030309

Zeng, Q. F., Bai, P., Wang, J. P., Ding, X. M., Luo, Y. H., Bai, S. P., Xuan, Y., Su, Z. W., Lin, S. Q., Zhao, L. J., \& Zhang, K. Y. (2015). The response of meat ducks from 15 to $35 \mathrm{~d}$ of age to gossypol from cottonseed meal. Poultry Science, 94(6), 1277-1286. https://doi.org/10.3382/ps/pev070 